J. Asiat. Soc. Bangladesh, Sci. 47(1): 13-22, June 2021 DOI: https://doi.org/10.3329/jasbs.v47i1.54183

\title{
COMPARATIVE STUDY ON PROXIMATE AND MINERAL COMPOSITION OF NATIVE AND HYBRID PANGAS (PANGASIUS PANGASIUS, P. HYPOPHTHALMUS) AT RAW AND FRIED STAGES
}

\author{
SADIA JAHAN ${ }^{1}$, A.H.M. SHAFIULLAH HABIB ${ }^{1} *$, SHANZIDA ISLAM ${ }^{2}$, \\ MD. KAMRUL HASAN ${ }^{1}$, MOHAJIRA BEGUM ${ }^{2}$ AND SHEKRITE BARDHAN ${ }^{1}$ \\ ${ }^{1}$ Department of Zoology, Jagannath University, Dhaka-1100, Bangladesh \\ ${ }^{2}$ Institute of Food Science and Technology (IFST), Bangladesh Council of Scientific \\ and Industrial Research (BCSIR), Dhaka-1205, Bangladesh
}

\begin{abstract}
A study was conducted on the proximate and mineral composition of native and hybrid pangas, namely Pangasius pangasius and Pangasius hypophthalmus at raw and fried stages between January and December 2017. At the raw stage higher amount of average protein $(23 \%)$ found in native pangas compared to hybrid $(19.7 \%)$ and hybrid pangas contain higher fat $(15.95 \%)$ compared to native $(12.75 \%)$, although the moisture content was the same in both. Protein and fat were higher in both fishes at $26.8 \%$ and $20.95 \%$ in natives and $24.05 \%$ and $24.2 \%$ in hybrids at the fried stage. At the raw stage, mineral contents were higher in natives and the highest content was sodium $(185.38 \mathrm{mg} / 100 \mathrm{~g})$ followed by phosphorus $(166.90 \mathrm{mg} / 100 \mathrm{~g})$ and calcium $(116.35 \mathrm{mg} / 100 \mathrm{~g})$ and slightly decreased those minerals at the fried stage of the same fish. In the fried stage, mineral contents were found almost the same, although calcium, magnesium, iron was slightly varied and phosphorus, sodium found high in amount. But energy level was higher (328 Kcal) in hybrids compare to native. Thus, the study of raw and fried stages indicates that native pangas are better in proximate and mineral composition than the hybrids, but the energy was high in hybrids.
\end{abstract}

Key words: Native and hybrid pangas, Proximate composition, Minerals, Raw stage, Fried stage.

\section{Introduction}

Bangladesh is an agro-based country blessed with vast inland water in the form of ponds, canals, ditches, flat plains, haors, baors, rivers, and estuaries covering 43.10 million hectares which is an excellent ecological condition for the propagation of fish (BBS 1994). Inland fish and fisheries play important roles in ensuring global food security.

*Corresponding author: <ahmshabib@gmail.com>. 
They provide a crucial source of animal protein and essential micronutrients for local communities, especially in the developing world (Youn 2014). The Food and Agriculture Organization (FAO) estimates that about one billion people world-wide rely on fish as their primary source of animal protein whether eaten raw or cooked, salted, smoked or preserved or any other way, the popularity of fish is worldwide (FAO 2008). Over 75\% of the global fish production is used for direct human consumption and the consumption of fresh fish is growing at the expense of other forms of fish products. The remaining fishes destine for non-food products, in particular the manufacture of fishmeal and fish oil (FAO 2008). The proportion of global fish production used for direct human consumption is now over 77\%, a significant rise of the last decades, with consumption of fresh fish outstripping other fish products such as canned fish (FAO 2016). However, wild fish is not sufficient for the current demand of the consumers and that's why fish culture is introduced to balance the demand and supply. Nowadays, to meet up the scarcity of fish protein, hybrid pangas are cultured everywhere in Bangladesh along with native pangas for nutritional values and many economic advantages. Wild and farmed fish vary in nutrients (Netteton and Exler 1992) as well as sensorial, chemical and physical properties (Love 1980).

The biochemical composition of fish varies from species to species and with the same species from one individual to another, individual variation usually is due to some factors such as size, age, season, sex and geographical location (Stansby 1962). The proximate composition generally comprises the estimation of moisture, protein, fat and ash contents of the fresh fish body. The percentage composition of these constituents accounts for about $96-98 \%$ of the total tissue constituents in fish (Nowsad 2007). The assessment of the fish's proximate composition is important to know its nutritive value, and its better processing and preservation (Mridha et al. 2005). In addition, estimation of the proximate profile of a fish is often necessary to ensure that they meet the requirements of food regulations and commercial specifications.

Fish is a high protein food consumed by a large percentage of the populace because of its high palatability, low cholesterol and tender flesh (Eyo 2001). It comprises all ten essential amino acids in desirable quantity for human consumption. Fish protein is very rich in such amino acids as methionine, lysine and low in tryptophan compared to mammalian protein (Nowsad 2007). Fish normally has more polyunsaturated fatty acids (PUFA) than animal fats. An increasing amount of evidence suggests that high content of PUFA in the fish flesh and fish oil are beneficial in reducing the serum cholesterol (Huynh et al. 2007). The latter, fish, is also a good source of vitamins and minerals viz., calcium, phosphorus, sodium, potassium, iron, manganese, zinc, copper, etc. They absorb 
minerals not only from their diets but also from the surrounding water via their gills and skin (Lall 2002). Generally, fresh fish contain a considerable amount of minerals, but processed fish such as dried fish have higher values (Kinsella 1986). The measurement of these micro-nutrients in fish will reveal their availability to fish consumers and thus give a room to prevent the resultant effects of their deficiencies. Consumption of fish and their products helps in preventing cardiovascular and other diseases (Cahu et al. 2004). Fish are a rich source of essential nutrients required for supplementing both infant and adult diets (Botta et al. 1978). Monalisa et al. (2013) worked on a comparative study of nutrient contents of native and hybrid Koi (Anabas testudineus) and Pangas (Pangasius pangasius, P. hypophthalmus) fish in Bangladesh. Zaman et al. (2015) determined nutrient contents of some popular freshwater and marine fish species of Bangladesh. Das et al. (2015) worked on microbiological and nutritional assessment of some selected cultured species. Hasan et al. (2018) worked on quality assessment of salt-cured spotted snakehead. The present study was conducted to elucidate the proximate and mineral composition of native and hybrid pangas at both raw and fried stages.

\section{Material and Methods}

The native fish samples of pangas (Pangasius pangasius) were collected from the Meghna River of Chadpur point (Site 1) and Meghna River of Bhairab Point (Site 2). On the other hand, the hybrid pangas (Pangasius hypophthalmus) were collected from a culture pond at Gazipur (Site 3) and a culture pond at Narsingdi (Site 4). After collection, fresh fish samples were taken to the Institute of Food Science and Technology Laboratory, BCSIR, Dhaka, for further laboratory analysis. The nutrient contents were estimated in two stages of the selected species, at raw and fried stages. The fishes were washed properly to avoid any germs, dirt, or infectious agents. Then fishes were degutted and washed again and chopped fish muscles on a hard-chopping board. The chopped muscles of fish were used for the analysis at the raw stage. At the fried stage, the fishes were washed and cleaned properly and degutted. The same fish muscles were fried with soybean oil for 3-4 minutes at $70-80^{\circ} \mathrm{C}$ and then other procedures were followed one by one as like that of raw stage.

Chemical analysis for moisture, protein, fat and ash were done following the standard method described in the AOAC manual (AOAC 2005). The loss of weight was calculated as percent moisture content using this formula:

$$
\text { Moisture }(\%)=\frac{\text { Loss in weight of sample }(\mathrm{g})}{\text { Weight of sample }(\mathrm{g})} \times 100
$$


Ash content was determined by wigniting sample about 4-5 g, in a Muffle Furnace burned at $400-500^{\circ} \mathrm{C}$ and calculated using following formula:

Ash $(\%)=\frac{\text { Weight of ash }(\mathrm{g})}{\text { Weight of sample }(\mathrm{g})} \times 100$

The Kjeldahl method was used to determine the protein content of the fish samples. The data were taken by doing duplicate analyses for protein. The following formulas were used:

Millieuivalent of nitrogen $(0.014) \times$ Titrant value $(\mathrm{ml}) \times$ Strength of $\mathrm{HCl}$

$\%$ of Nitrogen $=\frac{\text { Weight of sample }(\mathrm{g})}{\text { W }}$

Crude Protein $(\%)=6.25 \times \%$ of Nitrogen

Lipid content was determined by Soxhlet apparatus using acetone as solvent. The percentage of total lipid was calculated by using the following formula:

Total lipid $(\%)=\frac{\text { Weight of lipid }(\mathrm{g})}{\text { Weight of sample }(\mathrm{g})} \times 100$

The carbohydrate content of samples was calculated using the following formula:

Carbohydrate $=100-(\%$ of moisture $+\%$ of protein $+\%$ of ash $+\%$ of fat $)$

The energy of the fish sample was calculated by the following formula:

Energy $=(\%$ of carbohydrate $\times 4.1)+(\%$ of protein $\times 4.1)+(\%$ of fat $\times 9.1)$

Calcium, magnesium are being determined by the titration method. The atomic absorption spectrophotometric method was used for the determination of iron $(\mathrm{Fe})$ phosphorous $(\mathrm{P})$, zinc $(\mathrm{Zn})$ and copper $(\mathrm{Cu})$. Sodium $(\mathrm{Na})$ was estimated with the flame photometer.

\section{Results and Discussion}

Proximate composition: In the raw stage, native pangas were enriched with moisture (61.92 \pm 1.22$)$, protein $(23.00 \pm 1.00)$ and ash $(1.30 \pm 0.10)$ than hybrid, which contained $61.74 \pm 0.44,19.70 \pm 0.80$ and $1.185 \pm 0.08$ on average, respectively. Hybrid pangas 
contained more fat $(15.95 \pm 0.25)$ and carbohydrate $(1.42 \pm 0.02)$ than native species (Table 1). This may occur as the different feeding habits and metabolism systems. Hybrid pangas contain more energy $(231 \pm 1.00)$ than the native species as it contains more fat value. The result is more or less similar to the findings of Monalisa et al. (2013). Begum et al. (2012) found very close moisture and fat value in domesticated stock of Pangasius hypophthalmus in laboratory condition.

Table 1. Proximate composition of native and hybrid pangas at a raw stage.

\begin{tabular}{lcccccc}
\hline Proximate & \multicolumn{3}{c}{ Native pangas } & \multicolumn{3}{c}{ Hybrid pangas } \\
\cline { 2 - 7 } composition & Site 1 & Site 2 & Average \pm SE & Site 3 & Site 4 & Average \pm SE \\
\hline Moisture (\%) & 60.70 & 63.15 & $61.92 \pm 1.22$ & 61.30 & 62.19 & $61.74 \pm 0.44$ \\
Protein (\%) & 24.00 & 22.00 & $23.00 \pm 1.00$ & 20.50 & 18.90 & $19.70 \pm 0.80$ \\
Fat $(\%)$ & 13.00 & 12.50 & $12.75 \pm 0.25$ & 15.70 & 16.20 & $15.95 \pm 0.25$ \\
Ash $(\%)$ & 1.20 & 1.40 & $1.30 \pm 0.10$ & 1.10 & 1.27 & $1.185 \pm 0.08$ \\
Carbohydrate $(\%)$ & 1.10 & 0.95 & $1.02 \pm 0.07$ & 1.40 & 1.44 & $1.42 \pm 0.02$ \\
Energy (Kcal) & 221.00 & 207.00 & $214.00 \pm 7.00$ & 232.00 & 230.00 & $231 \pm 1.00$ \\
\hline
\end{tabular}

The proximate composition of native and hybrid pangas (Table 2) indicates that moisture content was significantly decreased in the fried stage, compared to the raw stage. It was observed that there is a great change in fat and protein contents between the raw and fried stage. In the fried stage, the values were high in both native and hybrid pangas from the raw stage. Sainani and Kapute (2017) found a decreased amount of moisture and a high amount of protein and fat content in the fried stage than the raw stage in Malawi tilapia (Oreochromis karongae), which are closely similar to the present finding.

At the raw stage, the higher moisture and ash content of native pangas (Pangasius pangasius) collected from site 2 was $63.15 \%, 1.4 \%$, respectively. The higher protein, fat, and carbohydrate estimated for native pangas from site 1 were $24 \%, 13 \%$ and $1.1 \%$, respectively (Fig. 1). On the other hand, the highest amount of moisture, fat and ash of hybrid pangas collected from site 4 was $62.19 \%, 16.2 \%$ and $1.27 \%$, respectively, but the highest protein content, 20.5\%, was found in the sample from site 3 (Fig. 2)

In the fried stage, the higher moisture, ash and carbohydrate contents of native pangas from site 2 were 50.3\%, 1.6\% and 1.39, respectively (Fig. 1). The higher protein and fat contents were estimated at $28.4 \%$ and $21.5 \%$ in the native sample from site 1 (Fig. 1). For hybrid pangas, the higher moisture $(49.02 \%)$, fat $(25.1 \%)$, ash $(1.51 \%)$ and carbohydrate $(1.87 \%)$ were found in the sample collected from site 4 (Fig. 2) and the highest protein $25.6 \%$ was estimated in the sample from site 3 (Fig. 2). 
Table 2. Proximate composition of native and hybrid pangas at the fried stage.

\begin{tabular}{lcccccc}
\hline Proximate & \multicolumn{3}{c}{ Native pangas } & \multicolumn{3}{c}{ Hybrid pangas } \\
\cline { 2 - 7 } composition & Site 1 & Site 2 & Average \pm SE & Site 3 & Site 4 & Average \pm SE \\
\hline Moisture (\%) & 47.20 & 50.30 & $48.75 \pm 1.55$ & 48.07 & 49.02 & $48.55 \pm 0.47$ \\
Protein (\%) & 28.40 & 25.20 & $26.80 \pm 1.60$ & 25.60 & 22.50 & $24.05 \pm 1.55$ \\
Fat (\%) & 21.50 & 20.40 & $20.95 \pm 0.55$ & 23.30 & 25.10 & $24.20 \pm 0.9$ \\
Ash (\%) & 1.57 & 1.60 & $1.58 \pm 0.01$ & 1.43 & 1.51 & $1.47 \pm 0.04$ \\
Carbohydrate (\%) & 1.30 & 1.39 & $1.34 \pm 0.04$ & 1.60 & 1.87 & $1.74 \pm 0.13$ \\
Energy (Kcal) & 316.00 & 304.00 & $310.00 \pm 6.00$ & 323.00 & 328.00 & $325.50 \pm 2.50$ \\
\hline
\end{tabular}

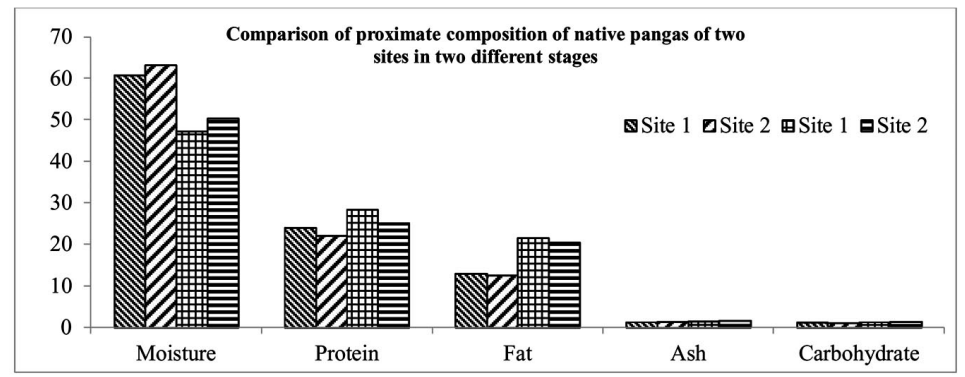

Fig. 1. Comparison of proximate composition of native pangas of two sites in two different stages.

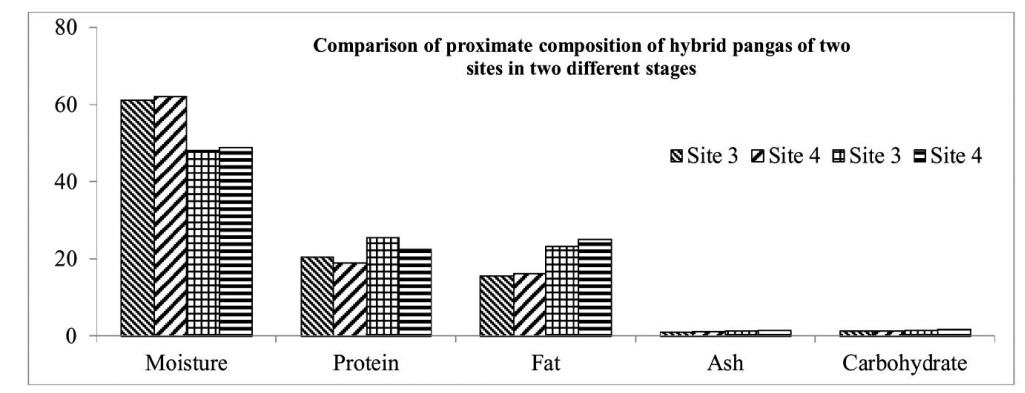

Fig. 2. Comparison of proximate composition of hybrid pangas of two sites in two different stages.

The highest protein content was $24 \%$ which has similar to the finding of Islam et al. 2012. They found $26 \%$ protein in native pangas. Begum et al. (2012) found $78.29 \%$ moisture in domesticated stock of Pangasius hypophthalmus in laboratory conditions. Islam et al. (2012) recorded $62.71 \%$ moisture, $11.1 \%$ fat and $23.18 \%$ protein value of hybrid pangas which are closely similar to the present finding. Hasan et al. (2018) recorded $74.14 \%$ moisture, $17.75 \%$ protein, $2.8 \%$ fat, $2.89 \%$ ash and $0.73 \%$ carbohydrate 
for Channa puncatus at the raw stage. There is a great change in fat and protein contents between the raw and fried stage due to heat. The amount other than moisture became a higher proportion because of water loss in the fried stage. (Tables 1-2). Mahaboob et al. (2018) had found a decreased amount of moisture and a high amount of protein and fat content in the fried stage than the raw stage, closely similar to the present findings.

Energy estimation: Higher energy was found in hybrid species $231 \pm 1.00$ as its fat content was higher in the raw stage and the freid stage, which was $316 \mathrm{Kcal}$ in native and 328 Kcal in hybrid species (Tables 1 and 2). Gopalan et al. (1971) reported $161 \mathrm{Kcal}$ for pangas fish which is quite different from the present finding. Hasan et al. (2018) found $101 \mathrm{kcal}$ for Channa punctatus in the raw stage.

The mineral content of native and hybrid pangas: At raw and fried stages, native pangas contained higher amount of sodium $(\mathrm{Na})$, calcium $(\mathrm{Ca})$, magnesium $(\mathrm{Mg})$, phosphorus $(\mathrm{P})$ and iron $(\mathrm{Fe})$, zinc $(\mathrm{Zn})$ and copper $(\mathrm{Cu})$ than the hybrid species (Tables 3 and 4). But in the case of the fried stage, it was observed that Fe was decreased in a very low concentration from the raw stages in both native and hybrid pangas (Tables 3 and 4). At both the raw and fried stage, the higher amount of sodium, magnesium, phosphorus, iron, zinc, copper for native pangas collected from site 1 was $190.5 \mathrm{mg} / 100 \mathrm{~g}, 48.5$ $\mathrm{mg} / 100 \mathrm{~g}, 170.3 \mathrm{mg} / 100 \mathrm{~g}, 4.74 \mathrm{mg} / 100 \mathrm{~g}, 0.90 \mathrm{mg} / 100 \mathrm{~g}, 0.43 \mathrm{mg} / 100 \mathrm{~g}$ and 198.2 $\mathrm{mg} / 100 \mathrm{~g}, 44.2 \mathrm{mg} / 100 \mathrm{~g}, 185.2 \mathrm{mg} / 100 \mathrm{~g}, 4.13 \mathrm{mg} / 100 \mathrm{~g}, 0.81 \mathrm{mg} / 100 \mathrm{~g}, 0.37 \mathrm{mg} / 100$ $\mathrm{g}$, respectively in the samples from site 2 (Fig. 3). The highest amount of calcium (122.5 $\mathrm{mg} / 100 \mathrm{~g}$ at raw and $110.2 \mathrm{mg} / 100 \mathrm{~g}$ at fried stage) was estimated in native species from site 2 (Fig. 3). For hybrid pangas, the highest amount of sodium $(105.3 \mathrm{mg} / 100 \mathrm{~g}$ and $116.6 \mathrm{mg} / 100 \mathrm{~g})$, calcium $(88.7 \mathrm{mg} / 100 \mathrm{~g}$ and $72.4 \mathrm{mg} / 100 \mathrm{~g})$, magnesium $(27.3 \mathrm{mg} / 100$ $\mathrm{g}$ and $25.3 \mathrm{mg} / 100 \mathrm{~g}$ ) and phosphorus $(133.2 \mathrm{mg} / 100 \mathrm{~g}$ and $142.4 \mathrm{mg} / 100 \mathrm{~g}$ ) were found in the sample from site 4 at both raw and fried stages, respectively (Fig. 4) but higher amount of iron $(1.61 \mathrm{mg} / 100 \mathrm{~g}$ and $1.3 \mathrm{mg} / 100 \mathrm{~g})$, zinc $(0.76 \mathrm{mg} / 100 \mathrm{~g}$ and $0.69 \mathrm{mg} / 100$ $\mathrm{g})$ and copper $(0.27 \mathrm{mg} / 100 \mathrm{~g}$ and $0.25 \mathrm{mg} / 100 \mathrm{~g})$ were estimated in samples of site 3 at both raw and fried stages respectively (Fig. 4).

Islam et al. (2012) reported the calcium content of native and hybrid Pangas $110 \mathrm{mg} / 100$ g. Native pangas contain a high amount of calcium content than the hybrid. This finding is quite similar to the investigation of Islam et al. (2012). The values of other minerals such as sodium, zinc, iron, and copper were more or less similar to the study of Monalisa et al. (2013). Hasan et al. (2018) found $381.2 \mathrm{mg} / 100 \mathrm{~g} \mathrm{Ca}, 105 \mathrm{mg} / 100 \mathrm{~g} \mathrm{Mg}, 68.6$ $\mathrm{mg} / 100 \mathrm{~g} \mathrm{P}$ and $11.4 \mathrm{mg} / 100 \mathrm{~g} \mathrm{Fe}$ in Channa punctatus in the raw stage. 
Table 3. Mineral content of native and hybrid pangas at a raw stage.

\begin{tabular}{lcccccc}
\hline Minerals & \multicolumn{3}{c}{ Native pangas } & \multicolumn{3}{c}{ Hybrid pangas } \\
\cline { 2 - 7 } $\mathrm{mg} / 100 \mathrm{~g}$ & Site 1 & Site 2 & Average \pm SE & Site 3 & Site 4 & Average \pm SE \\
\hline Sodium $(\mathrm{Na})$ & 190.50 & 180.25 & $185.38 \pm 5.12$ & 95.70 & 105.30 & $100.50 \pm 4.80$ \\
Calcium $(\mathrm{Ca})$ & 110.20 & 122.50 & $116.35 \pm 6.15$ & 75.36 & 88.70 & $82.03 \pm 6.67$ \\
Magnesium $(\mathrm{Mg})$ & 48.50 & 42.31 & $45.40 \pm 3.09$ & 23.05 & 27.30 & $25.17 \pm 2.12$ \\
Phosphorus (P) & 170.30 & 163.50 & $166.90 \pm 3.40$ & 122.50 & 133.20 & $127.85 \pm 5.35$ \\
Iron (Fe) & 4.74 & 4.50 & $4.62 \pm 0.12$ & 1.61 & 1.52 & $1.56 \pm 0.04$ \\
Zinc (Zn) & 0.90 & 0.81 & $0.85 \pm 0.04$ & 0.76 & 0.72 & $0.74 \pm 0.02$ \\
Copper $(\mathrm{Cu})$ & 0.43 & 0.37 & $0.40 \pm 0.03$ & 0.27 & 0.24 & $0.25 \pm 0.01$ \\
\hline
\end{tabular}

Table 4. Mineral content of native and hybrid pangas at the fried stage.

\begin{tabular}{lcccccc}
\hline Minerals & \multicolumn{3}{c}{ Native pangas } & \multicolumn{3}{c}{ Hybrid pangas } \\
\cline { 2 - 7 } $\mathrm{mg} / 100 \mathrm{~g}$ & Site 1 & Site 2 & Average \pm SE & Site 3 & Site 4 & Average \pm SE \\
\hline Sodium $(\mathrm{Na})$ & 198.20 & 192.40 & $195.30 \pm 2.90$ & 104.60 & 116.60 & $110.60 \pm 6.00$ \\
Calcium $(\mathrm{Ca})$ & 96.50 & 110.20 & $103.35 \pm 6.85$ & 67.30 & 72.40 & $69.85 \pm 2.55$ \\
Magnesium $(\mathrm{Mg})$ & 44.20 & 39.70 & $41.95 \pm 2.25$ & 20.40 & 25.30 & $22.85 \pm 2.45$ \\
Phosphorus $(\mathrm{P})$ & 185.20 & 177.02 & $181.11 \pm 4.09$ & 131.07 & 142.40 & $136.73 \pm 5.66$ \\
Iron $(\mathrm{Fe})$ & 4.13 & 4.03 & $4.08 \pm 0.05$ & 1.30 & 1.27 & $1.28 \pm 0.01$ \\
Zinc $(\mathrm{Zn})$ & 0.81 & 0.74 & $0.77 \pm 0.03$ & 0.69 & 0.67 & $0.68 \pm 0.01$ \\
Copper $(\mathrm{Cu})$ & 0.37 & 0.32 & $0.34 \pm 0.02$ & 0.25 & 0.20 & $0.22 \pm 0.02$ \\
\hline
\end{tabular}

The study indicated that native pangas are a good source of minerals than hybrid pangas. (Tables 3-4). This study may be useful in developing nutrient-balanced and costeffective diets for consumers.

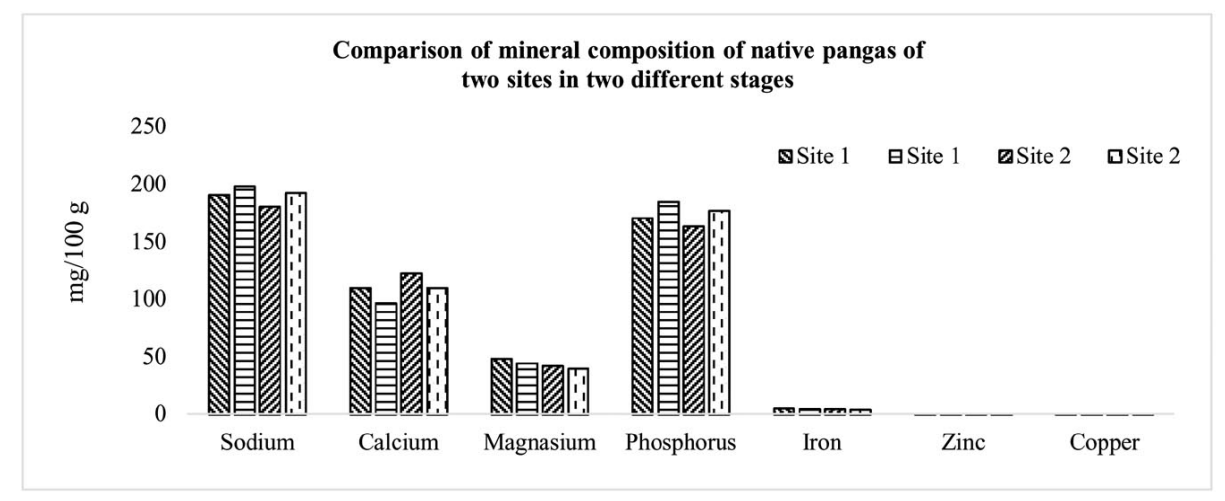

Fig. 3. Comparison of mineral content of native pangas of two sites in two different stages. 


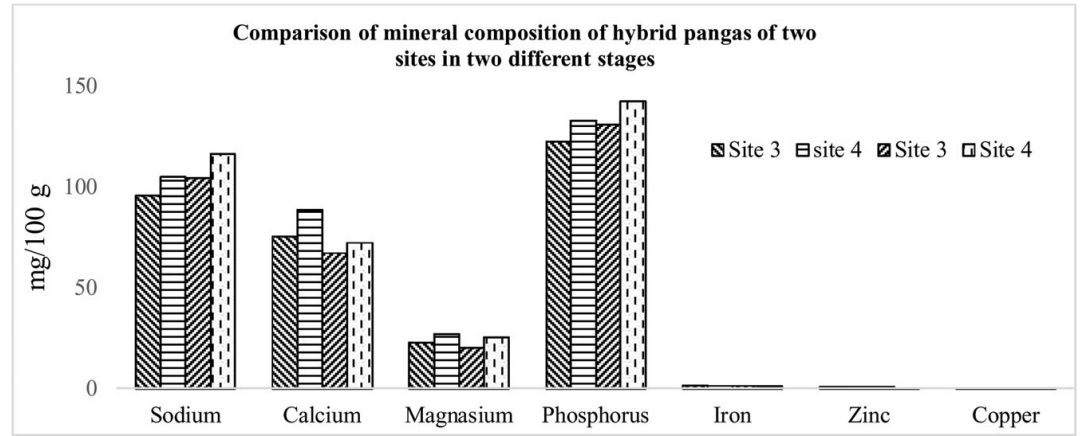

Fig. 4. Comparison of mineral content of hybrid pangas of two sites in two different stages.

The present study has elucidated the importance of native and hybrid species by estimating proximate and mineral composition. Since hybrid fishes are now very popular in rural and urban areas, there are still some confusions to the consumers about the nutrition of hybrid ones. The hybrid species contain more fat content than the native. Native pangas contain a significant amount of protein compared to the hybrid. The examined native fishes had appreciable $\mathrm{Na}, \mathrm{Ca}, \mathrm{Mg}, \mathrm{Fe}, \mathrm{P}, \mathrm{Zn}$ and $\mathrm{Cu}$ than hybrid fishes. There is no significant effect on mineral composition after frying compared to the raw fish. This study may be helpful in developing nutrient-balanced and cost-effective diets for consumers.

\section{References}

AOAC. 2005. Official Methods of Analysis. 8th edn. Association of Official Analytical Chemists, Washington DC, USA.

BBS, 1994. Bangladesh Bureau of Statistics, Statistics Year Book of Bangladesh. Govt. of Bangladesh, Bangladesh Secretariat, Dhaka, pp. 735.

Begum, M. F. Akter, A.T.A. Ahmed and M.A. Khaleque. 2012. Comparison and quality Assessment of dried punti fish (Puntius sophore; Hamilton-Buchanan, 1822) both at commercial and laboratory level. Int. J. Sustain. Agril. Tech. 8(8): 45-51.

Botta, J.R., P.B. Noonan and J.T. Lauder. 1978. Chemical and sensory analysis of ungutted offshore capelin (Mallotus villous) stored in ice. J. Fish 35: 971-980.

Cahu, C., P. Salen and M.D. Lorgeril, 2004. Farmed and wild fish in prevention of cardiovascular disease assessing possible differences in lipid nutritional values. Nutrition Metabolism Cardiovascular Disease 14: 34-41.

Das, S., A. Hasan, S. Hossain, P. Parveen and F.M. Juliana. 2015. Microbiological quality assessment of cultured fish samples collected from ponds and different local markets of Bangladesh. International J. Innovative Research in Science, Engineering and Technology 4: 8979-8984

Eyo, A.A. 2001. Fish processing technology in the tropics, University of Ilorin Press. pp. 403.

FAO, 2008. The State of Food and Agriculture. Food and Agriculture Organization of the United Nations, Rome. 
FAO, 2016. Fisheries and Aquaculture topics. Fish and seafood utilization. Topics Fact Sheets. In: FAO Fisheries and Aquaculture Department [online] Rome.

Gopalan, C., R.B.V. Sastri and S.C. Balasubramanian. 1971. Nutritive value of Indian foods. Hydrabad, India. J. Nutrition Education 2(3): 115.

Hasan, M.K., A.H.M.S. Habib, S. Islam, S. Jahan and M. Begum. 2018. Quality assessment of salt cured spotted snakehead, Channa punctatus. Jagannath University, J. Life and Earth Sciences 4(2): 103-113.

Huynh, M.D., D.D. Kitts, C. Hu and A.W. Trites. 2007. Composition of fatty acid profiles of spawning and non-spawning Pacific herring, Clupea harengus pallasi. Comparative Biochemistry and Physiology 146: 504-511.

Islam, M.J., M. Kamrunnaher, T Khan and A.T.M. Abdullah. 2012. Comparative study on nutrient contents of native and hybrid Koi (Anabas testudineus) and pangas (Pangasius pangasius, Pangasius hypophthalmus) fish in Bangladesh. International Food Research Journal 20: 791797.

Kinsella, J.E. 1986. Food Components with Potential Therapeutic Benefits: The n-3 Poly unsaturated Fatty acids of Fish Oils. Food Technology 40(2): 89-97.

Lall, S.P. 2002. The Minerals. In: Fish Nutrition, $3^{\text {rd }}$ ed. (Eds. J.E. Halver and R. W. Hardy). Academic Press, San Diego, CA, pp. 259-308.

Love, R.M. 1980. The Chemical Biology of Fishes. 2: Advances 1968-1977. Academic Press London.

Mahaboob, S., K.A. Al-Ghanim, H.F.A. Al-Balawi, F. Al-Misned and Z. Ahmed. 2018. Study on assessment of proximate composition and meat quality of fresh and stored Clarias gariepinus and Cyprinus carpio. Brazilian J. Biol. 79(4):

Monalisa, K., M.Z. Islam, T.A. Khan, A.T.M. Abdullah and M.M. Hoque. 2013. Comparative study on nutrient contents of native and hybrid climbing perch (Anabas testudineus) and pangas (Pangasius pangasius, Pangasius hypophthalmus) fish in Bangladesh. International Food Research Journal 20(2): 791-797.

Mridha, M.A., S.Y. Lipi, N.T. Narejo, M.S. Uddin, M.S. Kabir and M. Karim. 2005. Determination of Biochemical Composition of Cirrhinusreba(Hamilton, 1822) from Jessore, Bangladesh, Journal of Science \& Technology University Peshawar 29(1): 1-5.

Nettleton, J. A. and J. Exler. 1992. Nutrients in wild and farmed shellfish. J. Food Science 57(2): 257-260.

Nowsad, A.K.M.A. 2007. Participatoty Training for Trainers: A New Approach Applied. In The Fish Processing. Bangladesh Fisheries Research Forum, pp. 213.

Sainani H. and F. Kapute. 2017. Effect of cooking method on proximate and mineral composition of Lake Malawi tilapia (Oreochromis karongae), African J. Food, Agriculture, Nutrition and Development 17(4): 12589-12599.

Stansby, M.E. 1962. Proximate Composition of Fish in Nutrition By Brik Heen and Rudolf Kronzer, Fishing News (Books). Ltd., Ludgate, 110 Floet Street, London, E.C.4, England.

Youn, S.J., W.W. Taylor, A.J. Lynch, I.G. Cowx, T.D. Beard, D. Bartley and F. Wu. 2014. Inland capture fishery contribution to global food security and threats to their future. Global Food Security 3(3):142-148.

Zaman, M., N. Naser, A.T. Abdullah and N. Khan. 2015. Nutrient contents of some popular freshwater and marine fish species of Bangladesh. Bangladesh J. Zool. 42: 251.

(Revised copy received on 17.03.2021) 